\title{
Teachers' Skills and ICT Integration in Technical and Vocational Education and Training TVET: A Case of Khartoum State-Sudan
}

\author{
Abdelmoiz Ramadan ${ }^{1,2}$, Xiaohui Chen ${ }^{1, *} \&$ Laura L. Hudson ${ }^{3}$ \\ ${ }^{1}$ School of Computer Science and Information Technology, Northeast Normal University, Changchun, Jilin, China \\ ${ }^{2}$ Ministry of Education, Technical and Vocational Education and Training, Sudan \\ ${ }^{3}$ School of Education, Northeast Normal University, Changchun, Jilin, China \\ *Correspondence: School of Computer Science and Information Technology, Northeast Normal University, No 2555 \\ Jingyue Street, Changchun 130000, Jilin Province, China. Tel: 0431-8453-6821. E-mail: chenxiaohui93@126.com
}

Received: April 3, 2018

Accepted: April 30, $2018 \quad$ Online Published: May 27, 2018

doi:10.5430/wje.v8n3p31

URL: https://doi.org/10.5430/wje.v8n3p31

\begin{abstract}
Information and communication technology (ICT) elicited rapidly dissemination over the world. For its impact in Sudan, the national government has been energized the institutions to implement ICT in every sector. This study examined the Sudanese teachers' skills and ICT integration in technical and vocational education and training TVET in Khartoum state. The study directed out of two hundred respondents were sampled randomly, questionnaires were distributed, 168 (84\%) were properly filled and returned, 130 were males and 38 females from three various bodies of TVET include (technical secondary schools, artisan institutions, and vocational training centres). A One-Way ANOVA and Independent sample t-test on SPSS version 20 for data analysis were adopted. The results revealed that significantly the respondents are same in terms of demographic information and ICTs usage skills. However, there was a significant difference among the respondents' ICT skill due to their ages and qualifications. Consequently, more training needs to be conducted for TVET teachers in basic skills of computer use. Following the international standards, the right decisions we are strongly recommending train/teach pre-service and in-service teachers on ICTs skills based on 21 st-century requirement.
\end{abstract}

Keywords: ICT applications, teachers' skills, TVET, Sudan

\section{Introduction}

Information and communication technology (ICT) is becoming the lead artery in our international system which transfers information and knowledge in various fields of professional development for the technical and vocational education system. Therefore, education is the main valve which is responsible for dissemination of knowledge and information technologies. In line with the fast pace of ICTs development; all the technical and vocational education and training TVET cadres (schools managers, teachers, students even the classrooms), should be prepared to meet the new culture of teaching and learning based on 21st century skill's requirements for educational technologies (Chai, Tan, Deng, \& Koh, 2017; Göksün \& Kurt, 2017) to produce and raise the number of knowledgeable and skilled students who will lead economic development, with Sudan is the focus of this particular investigation.

Many studies had been conducted in ICT field in Sudan but all those studies focused on the general education system (A. Ahmed, 2015; Alamin \& Elgabar, 2014; Elemam, 2016; Tairab, Huang, Chang, \& Zheng, 2016; Tairab \& Ronghuai, 2017), but this study focused on TVET teachers skills in particular according to the needs of qualified teachers who might serve both teaching experiences based on ICT applications as a theoretical subject in the classroom from one side and practical issues inside the workshop from another as well as managerial purposes.

The national policy by the Sudanese government supports the development of ICT in order to achieve government project goals through extending network range, providing access to government websites to the people through the availability of electronic services which has been made in regards to healthcare, agriculture and commercial activity MCIT-Sudan, Oct 2017. However, in the educational field, the government has less significantly prioritized ICT development, because as the head of the Ministry of Communication and Information Technology MCIT-Sudan, declares that "educational sector is not ready for such interaction with the MCIT to work together to overcome such 
issue" (ibid). According to this point of view, the existence of ICT integration in the governments' organizations refers to their understanding of ICT and its impact. While it might be integrated with a great interest in the curriculum by the students, teacher training and capacity building as the strategic role of Federal Ministry of General Education (FMGE) as well as provided the educational resources in rural areas for nomadic people, the political spirit, at this time, is lacking. (Hamdy, 2007) reported that in the year 1999 Sudan's national strategy of ICT integration focused on the most important five target areas "the technology infrastructures and human resources" among them, where the technical and vocational education and training are there. Additionally, the national curriculum center and educational research NCCER is one of Sudan's FMGE administrations in coordination with the Information Directorate ICT policy for education was initiated in the year 2002. Hence, computer science introduced as curriculum in a secondary school in the year 2004, as a result, $50 \%$ of Sudanese secondary schools were provided computers and internet connectivity, within these circumstances all the general curriculum textbooks were converted into digital textbooks, available on CD-ROM. Computers should cover all public and higher education systems in Sudan according to the Geneva agreement 2015 (ibid).

Based on the researcher's experiences as a staff member in the field of TVET in the school year 2014/2015 was the first time the student taught the subject of computer science, as one of the privacy policies of national council of technical and technological education (NCTTE) the computer science has been implemented in technical secondary schools and artisan institutions based on the FMGE policies, as general curriculum and as a specialized department, but has not been implemented in all of the technical secondary schools in Khartoum state where computer science was taught neither theoretical subject or practical. Perhaps these refer to the case of many barriers such as lack of computer devices (Tairab et al., 2016) and core teachers who teach this subject as it was reported by the previous studies (A. Ahmed, 2015; Elemam, 2016). From this point of view, when TVET is equipped with adequate laboratories and professional teachers for computer science, the teachers have a chance to get some experiences of using computer whether from their colleagues or students with regards to their students' learning of computer science.

In today's world, teachers' skills are a vital component of the society in order to upgrade students' learning achievements. Meeting the needs of economic development in developing country like Sudan, who struggles with the late progression in ICT integration in teaching and learning process due to weaknesses of its implementation efforts, school infrastructure (multimedia, digital learning materials), not having enough qualified teachers and in the absence of educational ICT policies or vision (H. Ahmed, 2010; Elemam, 2016; Tairab et al., 2016). Although, studies in this field recently looked at how ICTs skills in the 21st century should be integrated into educational processes and the characteristics of teachers and learner based on; teaching competences (Guzman \& Nussbaum, 2009), teacher development of TPACK (Chai, Koh, \& Tsai, 2010), teachers and learners skills based on this era (Göksün \& Kurt, 2017). The current study attempts to assess the TVET teachers' skills level in ICT application use and its integration in the classrooms particularly with regard to the basic skills of computer technologies use in Sudan.

\subsection{The Impact of ICT Use on TVET System}

Information and communications technologies ICT within education are increasing exponentially because of the technological progression and social needs. Therefore, ICT represents a master key which can pave the way for the educational system globally to upgrade student knowledge and abilities. For example, (Law, 2000) argues that "teachers progressively increase information when the classrooms environments are ready for ICT integration". In other words, the factors that lead to the successful use of ICT in the classroom are components that include, developing technological infrastructure, and educator accessibility, technical support, human resources (teachers, principals, and IT team existence) and their beliefs in ICT and institutional vision (Tsai \& Chai, 2012). (Peeraer \& Van Petegem, 2011) have explained the advantages of ICT as developing students' learning through the presentations which prepared by teachers, could be managed to get up-to-date knowledge and information that will refer to both teachers and students and, could improve school management systems instead of traditional teaching and management methods.

(Shamim \& Raihan, 2016) conducted a study about the effectiveness of ICT use to promote teaching and learning in technical education in Bangladesh, which revealed that ICT, facilitates teaching and learning, for time-saving when compared with traditional teaching. Moreover, ICT training offers many benefits to the educational system in general whether in teaching and learning, management and student assessment. Therefore, in order to infuse ICTs in TVETs system, teaching in this system is no longer easier than academic education. While academic knowledge depends on theories and application, many TVET courses require a multi-disciplinary approach, combining wide-ranging skill 
sets (Abdulrasool \& Mishra, 2009; Alseddiqi, Mishra, \& Abdulrasool, 2010; Bezjak, 2010; Jamšek \& Kocijancic, 2007). Utilizing technology in classrooms could greatly aid teachers in facilitating the education of complex skill sets for students (Latchem, 2017; Union, 2007). Thus, the logical questions that must be put them out, can lead us to understand what are the skill sets that TVET teachers possessed which assist in enhancing the students' inspiration for their enrolment in order to reverse drop-out rates in the TVET system not only in Sudan but in all of Africa (Mingaine, 2013). ICT needs to be incorporated into the curriculum by effective teachers who make learning interesting, enjoyable, to motivate students and to allow them to practice skills they will need in their everyday work life (Tella, Tella, Toyobo, Adika, \& Adewuyi, 2007). When there is adequate awareness about the state of teacher training in regards to ICT skills and usage within the classrooms of TVET education, hopefully, interested parties will reform the system in order to provide students with the educational training needed to ensure successful implementation.

\subsection{Teachers' Skills Towards ICT}

(Demetriadis et al., 2003) state that "if educators do not have sufficient abilities for handling a computer, improbably they will be able to incorporate technology into their classroom teaching". (Elstad \& Christophersen, 2017; Hatlevik, Scherer, \& Christophersen, 2017) reported from their research that $56.6 \%$ of upper secondary students believe their professors have no knowledge of computer use. Keeping that overwhelming statistic in mind, assessing the basic levels of current teacher engagement with computer skills such as word processing (Hyland, 1990), handling files, spreadsheets database, e-mail and uses of social media through an internet connectivity needs to be the starting points for this study.

(Tella et al., 2007) demonstrate that possessing these fundamental skills stimulate the school's management performance and communication processes between teachers, administrators, parents, and students. Additionally, internet usage skills encourage teachers to collaborate in online enhancement of their own knowledge through the educational platforms and search engines (i.e. google, wiki,) for discovering new information in order to enrich their students' classroom experience with fresh knowledge, developing their skills and problems solving when modeling and simulation are used in TVET classrooms teaching (ibid).

Some studies revealed that at the present time teachers represented as the "Digital Native" users, or the first generation of students to grow up using computer technology, facilitate the usage of educational technologies and digital materials in the education system (Bennett, Maton, \& Kervin, 2008; Elstad \& Christophersen, 2017). (Alazam, Bakar, Hamzah, \& Asmiran, 2012) conducted a study regarding teachers' skills and ICT integration with TVET program in Malaysia, the result demonstrates that the significant affiliation between ICT use and teachers' skills. The skills were low among teachers and the disparities demographically due to age; this confirmed that there is a relationship between age and teachers' beliefs with respect to ICT skills and its practices. Therefore, teachers' beliefs were signified as one of the factors that constrain ICT integration all over the world (Tsai \& Chai, 2012), as well as years of experience and performance (Boyd, Lankford, Loeb, Rockoff, \& Wyckoff, 2008; Elstad \& Christophersen, 2017). As a result, there will be a new pattern for learners and teachers to meet the contemporary demand in the digital era. In other words, teaching and learning processes might build up a sideways with digital age requisites (Melvin, 2011).

Many studies demonstrated that the new generation of ICT users (Chai et al., 2017; Göksün \& Kurt, 2017) and skills for teaching and learning processes particularly with the pre-service teachers are vital for improving conditions with respect to integrating digital technologies into TVET program. This study categorized them into three phases according to the current demands of Sudanese TVET teachers. When these steps were implemented, they would be able to reach and achieve the standardization of the developed world.

The first step: is curriculum (Ananiadou \& Claro, 2009) argued that the curriculum might draw the learner skills track for example like; creative thinking, communication, research, problem-solving, decision making and, information and communication technology skills. In order to do this, teachers will have to become familiar with vast amounts of new software programs and teaching strategies to facilitate the integration of these skills digitally (Tairab et al., 2016).

The second step: is that students initially have to be prepared to overcome barriers with the digital literacy skills so as to express knowledge inquisitiveness, confidence in the media utilization and building up skills through technology integration of the curriculum (Trilling \& Fadel, 2009). Trilling and Fadel, explains these skills clearly and classified digital literacy skills to comprise: firstly; the information literacy skill which allows students to access information effectively and productively, to assess information with critical and holistic perspective and to use this information accurately and creatively. Secondly; the media literacy which reflects the skills of the 21 st-century 
learner to use media and communication tools such as; videos, podcasts, web pages, and web 2.0 tools in the process of learning. Finally, information and communication technologies literacy express the skills of integrating and using digital tools like; computers, tablets and mobile devices in the learning process in an effective way (ibid).

The last step: is talking about teaching skills, 21st-century teachers skills as they had been discussed by (Göksün \& Kurt, 2017) based on the use of competencies and skills internationally and employing these skills into the classrooms in order to meet the digital learner needs. According to the global society for technology in education ISTE (ISTE, 2015; 2017; as cited in (Göksün \& Kurt, 2017) teacher are a dominant factor with regard to the students learning anticipated in support, stimulation and empowering them to strengthen their creative and innovative thinking, problem-solving skills in real life through technology use.

In order to remedy the lack of teacher skills in regards to ICT applications in TVET classrooms, "teachers require extensive on-going exposure to ICTs". Consequently, this study intends to evaluate the in-service teachers in Sudan in regards to the basic skills of computer use.

This paper examined Sudanese TVET teachers' skills with ICTs use in Khartoum State. The following research questions guided the study:

1. To what extent do the ICT skills differ among TVET teachers due to their demographic factors?

2. What are the basic levels of ICT skills of TVET teachers?

\section{Methodology}

The quantitative questionnaire used for this study for data collection from technical and vocational education and training. The teachers were employees of technical secondary schools, Artisan institutions, and Vocational training centres Khartoum state - Sudan.

\subsection{Sampling}

The population of this study consists of TVET teachers who were teaching the technical subjects in Khartoum state, the capital of Sudan. There were (six technical secondary schools, four artisan institutions and three vocational training centers) which represent 13 out of 19 schools within the TVET system at Khartoum state which consists of seven local administrations, one technical school from each, artisan institutions and vocational training centers as well as a representative sample which concerning all the teachers are in same characteristics. Therefore, the teachers were selected randomly for this study.

\section{Demographic Information:}

Table 1. Demographic Characteristic of Respondents $(\mathrm{N}=168)$

\begin{tabular}{lll}
\hline & Categories & $\mathbf{n}(\mathbf{\%})$ \\
\hline \multirow{3}{*}{ Gender } & Male & $130(77.4 \%)$ \\
& Female & $38(22.6 \%)$ \\
& $(20-24)$ & $4(2.4 \%)$ \\
Age (Years) & $(25-29)$ & $11(6.5 \%)$ \\
& $(30-34)$ & $24(14.3 \%)$ \\
& $(35-39)$ & $33(19.6 \%)$ \\
& $(40+)$ & $96(57.1 \%)$ \\
& & \\
Teaching experience & $(0-4)$ & $13(7.7 \%)$ \\
& $(5-9)$ & $30(17.9 \%)$ \\
& $(10-14)$ & $40(23.8 \%)$ \\
& $(15-19)$ & $62(36.9 \%)$ \\
& $(20+)$ & $23(13.7 \%)$ \\
& & \\
Teachers Qualifications & Others & $87(51.8)$ \\
& Bachelor & $70(41.7 \%)$ \\
& Master & $8(4.8 \%)$ \\
& Ph.D. & $3(1.8 \%)$ \\
\hline
\end{tabular}


The greatest number of respondents was male. Out of 168 respondents, $n=130(77.4 \%)$ were male teachers, while corresponding $n=38$ were female, which represents $(22.6 \%)$ of the respondents.

The largest age group were teachers that were 40 years old or more and they represented $n=96(57.1 \%)$ of the total population, followed by $35-39$ years old, which had $n=33$ or $(19.6 \%)$ of the population. (30-34) years old represented $\mathrm{n}=24(14.3 \%)$ was next, followed by $(25-29)$ years old which was represented by $\mathrm{n}=11(6.5 \%)$. The last category ranged (20-24) years old they were 4 teachers represented only $(2.4 \%)$.

The group with the highest range of teaching experience was found to be between (15-19) years which was represented by $\mathrm{n}=62$ from the study sample the percentage was $(36.9 \%)$ among teachers, followed by (10-14) years teaching 40 represented (23.8\%). A (5-9) year of experience, representing $30(17.9 \%)$ on the other hand was placed third. More than 20 years $n=23(13.7 \%)$ and only $13(7.7 \%)$ teachers who had less than 5 years of experience fill in the later range.

For the teacher's academic qualifications statistically, the highest frequencies and the percentage were "others" which includes (Artisan, vocational or secondary school certificates, Diploma and higher diploma) 87 of teachers they had represented (51.8\%). But, the actual level of teachers' qualifications was a Bachelor degree which had 70 (41.7\%); while the Master degree was $8(4.8 \%)$ and only $3(1.8 \%)$ represented $\mathrm{PhD}$ among the respondents.

\subsection{Instrumentation}

The questionnaire was developed in (Arabic), which is the native language of Sudan and then the instrument has been translated into the English language. The questionnaire was given in two parts; part one contained the teacher's demographic information (gender, age, years of teaching experience, qualifications); part two holds four subsections within 20 structured items on variables so as to measure the TVET teachers' skills. These variables are classified into four categories, that is five items representing Word processing skills, four items representing Spreadsheet and database, five items representing Handling files and six items representing Internet usage, 5 -point Likert scale ( $1=$ Strongly disagree, 2 = Disagree, $3=$ Not sure, $4=$ Agree, $5=$ Strongly agree) has been used for assessing the respondent's skills. This questionnaire was modified from (National College for Teaching and Leadership, 2015).

\subsection{Data Collection and Analysis}

The researcher distributed the questionnaires randomly to TVET teacher at Khartoum state. Out of two hundred questionnaires that were distributed to the teachers, 168 questionnaires were returned, hence relative rate $84 \%$ participation was observed. After that, the researcher adopted SPSS 20 software for data analysis through the frequencies and percentage for demographic information, mean (M) and standard deviation (S.D) to analyze the basic ICT skill sets of teachers.

\section{Results}

\section{a) Research question 1: Differences between TVET Teachers' ICT skills due to their demographic factors}

The study examines the difference of ICT skills based on demographic variables. To analyze this One-Way ANOVA was conducted on each skill based on (Gender, Age, Years of experience and Qualifications) the skills are as presented as in Tables 2, 3, 4, 5 respectively.

\subsection{ICT and Gender}

To examine the differences in ICT skills based on male and female an independent T-test was conducted as presented as in Table 2 shows that there was no statistically significant difference reported in whole levels of ICT skills among teachers. Males and females were same scores in the Word processing skills $(\mathrm{M}=12.95 ;$ S.D. $=6.15)$ and male $(\mathrm{M}=12.67$; S.D. $=6.61) ; \mathrm{t}(166)=-.232, \mathrm{P}=.817$.

Table 2. Teachers ICT Skills Based on Gender $(\mathrm{N}=168)$

\begin{tabular}{lllllll}
\hline & Categories & M & S.D. & df & F & P \\
\hline \multirow{2}{*}{ Total Word Processing } & Male & 12.67 & 6.61 & & & \\
Total & Female & 12.95 & 6.15 & 166 & .054 & .817 \\
& & 12.73 & 6.49 & & & \\
\multirow{2}{*}{ Total Spread sheet } & Male & 11.43 & 5.14 & & & \\
Total & Female & 12.16 & 4.62 & 166 & .615 & .434 \\
& & 11.60 & 5.02 & & & \\
\hline
\end{tabular}




\begin{tabular}{lllllll}
\hline Total Handling files & Male & 12.92 & 6.27 & & & \\
Total & Female & 14.21 & 6.05 & 166 & 1.275 & .260 \\
& & 13.21 & 6.23 & & & \\
Total Internet usage & Male & 14.63 & 7.48 & & & \\
Total & Female & 14.32 & 7.75 & 166 & .051 & .821 \\
\hline
\end{tabular}

\subsection{ICT and Age}

To examine the differences in ICT skills based on age the One -Way ANOVA result as presented in Table 3 shows that there was no statistically significant difference stated in the level of Word Processing and Spreadsheet skills. However, there was a significant difference in Handling files $(F=3.071), p=0.018)$ and Internet usage $(F=3.767)$, $\mathrm{p}=0.006$ ). When a post hoc test using pairwise comparison and a Bonferroni adjustment was conducted, there was significant difference in internet usage between ages 25-29 [( $\mathrm{M}=9.27, \mathrm{SD}=3.55), \mathrm{F}(4,163)=3.07, \mathrm{P}=.009]$, and $30-34[(\mathrm{M}=18.25, \mathrm{SD}=6.46), \mathrm{F}(4,163)=3.767, \mathrm{p}=.009]$.

Table 3. Teachers ICT Skills Based on Age $(\mathrm{N}=168)$

\begin{tabular}{|c|c|c|c|c|c|c|}
\hline & Categories & M & S.D. & df & $\mathbf{F}$ & $\mathbf{P}$ \\
\hline \multirow{5}{*}{ Total Word Processing } & $20-24$ & 9.25 & 3.10 & \multirow{6}{*}{4,163} & \multirow{6}{*}{2.116} & \multirow{6}{*}{.081} \\
\hline & $25-29$ & 11.64 & 7.06 & & & \\
\hline & $30-34$ & 16.00 & 5.36 & & & \\
\hline & $35-39$ & 12.76 & 7.11 & & & \\
\hline & $40+$ & 12.18 & 6.40 & & & \\
\hline \multirow[t]{3}{*}{ Total } & & 12.73 & 6.49 & & & \\
\hline & $20-24$ & 9.50 & 3.87 & \multirow{6}{*}{4,163} & \multirow{6}{*}{1.950} & \multirow{6}{*}{.105} \\
\hline & $25-29$ & 9.27 & 5.24 & & & \\
\hline \multirow[t]{3}{*}{ Total Spread sheet } & $30-34$ & 13.63 & 4.33 & & & \\
\hline & $35-39$ & 12.06 & 5.12 & & & \\
\hline & $40+$ & 11.28 & 5.06 & & & \\
\hline \multirow[t]{3}{*}{ Total } & & 11.60 & 5.022 & & & \\
\hline & $20-24$ & 7.75 & 2.06 & \multirow{6}{*}{4,163} & \multirow{6}{*}{3.071} & \multirow{6}{*}{.018} \\
\hline & $25-29$ & 10.18 & 4.10 & & & \\
\hline \multirow[t]{3}{*}{ Total Handling files } & $30-34$ & 16.29 & 5.59 & & & \\
\hline & $35-39$ & 12.82 & 6.97 & & & \\
\hline & $40+$ & 13.15 & 6.05 & & & \\
\hline Total & & 13.21 & 6.23 & & & \\
\hline \multirow{5}{*}{ Total Internet usage } & $20-24$ & 8.25 & 2.22 & \multirow{6}{*}{4,163} & \multirow{6}{*}{3.767} & \multirow{6}{*}{.006} \\
\hline & $25-29$ & 9.27 & 3.55 & & & \\
\hline & $30-34$ & 18.25 & 6.46 & & & \\
\hline & $35-39$ & 14.18 & 8.87 & & & \\
\hline & $40+$ & 14.63 & 7.27 & & & \\
\hline Total & & 14.56 & 7.52 & & & \\
\hline
\end{tabular}

\subsection{ICT and Teaching Experience}

To examine the differences in ICT skills based on teaching experience the One -Way ANOVA result as presented as in Table 4 shows that there was no statistically significant difference reported in the overall level of skills. Although, the Internet usage scored higher mean $(\mathrm{M}=16.65$, S.D. $=8.03)$, when a post hoc test using pairwise comparison and a Bonferroni adjustment was conducted the skills of internet usage possessed to respondents' experiences ranged between (0-4) level at $\mathrm{P}=>.06$ as Internet usage skills among the respondents. 
Table 4. Teachers ICT Skills Based on Teaching Experience $(\mathrm{N}=168)$

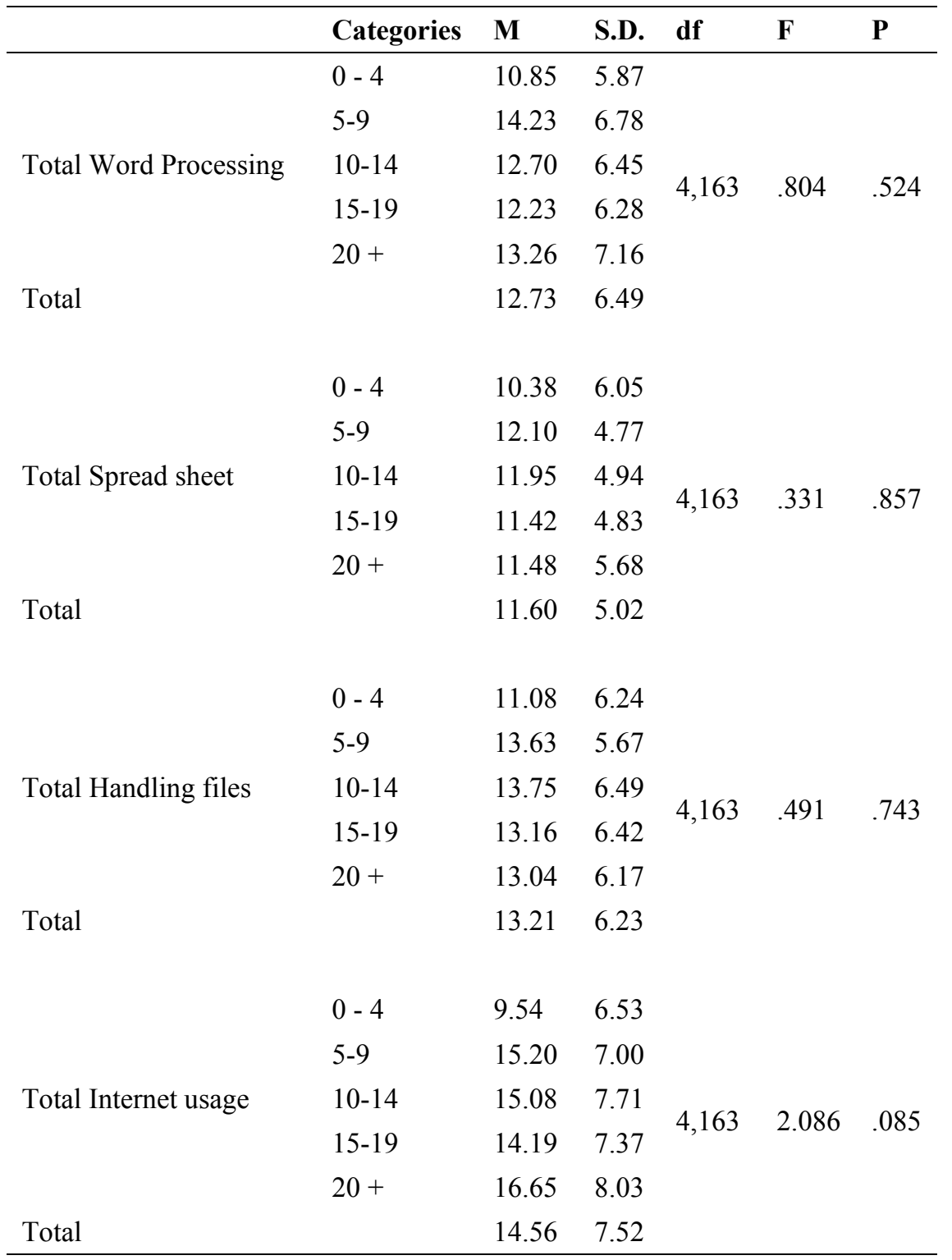

\subsection{ICT and Teaching Qualifications}

To examine the differences in ICT skills based on qualifications the One -Way ANOVA result as presented in Table 5 shows that there was statistically significant difference in the level of Word Processing $[(\mathrm{M}=13.93 ; \mathrm{SD}=6.76), \mathrm{F}$ $(4,163)=2.956, \mathrm{P}=.034]$, and Spreadsheet skills $[(\mathrm{M}=12.34 ; \mathrm{SD}=5.36), \mathrm{F}(4,163)=2.904, \mathrm{p}=.037)]$. However, when a post hoc test using pairwise comparison and a Bonferroni adjustment was conducted there was no significant difference level at $\mathrm{P}=>.22$ as Word processing besides spreadsheet and database skills with $\mathrm{P}=>.07$ among the respondents. 
Table 5. Teachers ICT Skills Based on Qualifications $(\mathrm{N}=168)$

\begin{tabular}{|c|c|c|c|c|c|c|}
\hline & Categories & $\mathbf{M}$ & S.D. & df & $\mathbf{F}$ & $\mathbf{P}$ \\
\hline \multirow{4}{*}{ Total Word processing } & $\mathrm{BSc}$ & 11.77 & 5.82 & & & \\
\hline & MSc & 10.63 & 7.69 & & & \\
\hline & $\mathrm{PhD}$ & 6.00 & 1.73 & 4,163 & 2.956 & .034 \\
\hline & Others & 13.93 & 6.76 & & & \\
\hline Total & & 12.73 & 6.49 & & & \\
\hline \multirow{4}{*}{ Total Spread sheet } & $\mathrm{BSc}$ & 10.91 & 4.37 & & & \\
\hline & MSc & 11.87 & 5.38 & & & \\
\hline & $\mathrm{PhD}$ & 5.00 & 1.73 & 4,163 & 2.904 & .037 \\
\hline & Others & 12.34 & 5.36 & & & \\
\hline Total & & 11.59 & 5.02 & & & \\
\hline \multirow{4}{*}{ Total Handling files } & $\mathrm{BSc}$ & 12.20 & 5.70 & & & \\
\hline & $\mathrm{MSc}$ & 11.38 & 5.10 & & & \\
\hline & $\mathrm{PhD}$ & 9.33 & 6.66 & 4,163 & 2.206 & .089 \\
\hline & Others & 14.32 & 6.57 & & & \\
\hline Total & & 13.21 & 6.23 & & & \\
\hline \multirow{4}{*}{ Total Internet usage } & $\mathrm{BSc}$ & 13.09 & 6.43 & & & \\
\hline & $\mathrm{MSc}$ & 12.38 & 7.80 & & & \\
\hline & $\mathrm{PhD}$ & 13.67 & 7.64 & 4,163 & 2.214 & .088 \\
\hline & Others & 15.98 & 8.13 & & & \\
\hline Total & & 14.56 & 7.52 & & & \\
\hline
\end{tabular}

b) Research question 2: the level of ICT skills of TVET teachers

To answer this question, for the analysis procedure the mean and standard deviation were used. And the highest levels of ICT skills among the teachers based on the four skills which had been measured, they were presented as follows.

Table 6. Word Processing Skills $(\mathrm{N}=168)$

\begin{tabular}{lll}
\hline Skills & M & S.D. \\
\hline Producing a text through a word processing program & 2.51 & 1.47 \\
Using basic Word functions & 2.63 & 1.46 \\
Using the toolbar for editing documents by picking font size style & 2.49 & 1.46 \\
Creating cells and tables to display information within a document & 2.58 & 1.44 \\
Saving a document or file in different formats (JPEG etc.). & 2.52 & 1.47 \\
Total & $\mathbf{2 . 4 7}$ & $\mathbf{1 . 1 7}$ \\
\hline
\end{tabular}

As shown in Table 6, the level of ICT skills among the subjects of word processing skill terms, the result showed that, the highest ICT skills teachers have been "the use of basic word functions" $(\mathrm{M}=2.63$; S.D. $=1.46)$, followed by "skills of creating cells and tables to display information within a document" $(\mathrm{M}=2.58$; S.D. $=1.44)$. "Saving a document and file in different formats (JPEG etc.)" $(\mathrm{M}=2.52$; S.D. $=1.47)$ was how the third set of skills ranked, 
followed by "producing a text through a word processing program" $(\mathrm{M}=2.51$; S.D. $=1.47)$ and finally "using of the toolbar for editing documents by picking font size style" $(\mathrm{M}=2.49$; S.D. $=1.46)$.

Table 7. Spreadsheets and Database Skills $(\mathrm{N}=168)$

\begin{tabular}{lll}
\hline Skills & M & S.D. \\
\hline It is easy to me use a spreadsheet & 2.82 & 1.41 \\
Entering numerical data into cells & 2.90 & 1.40 \\
Using Excel tools to add up totals on a spreadsheet & 2.95 & 1.38 \\
Using a spreadsheet to create a database & 2.92 & 1.37 \\
Total & $\mathbf{2 . 9 1}$ & $\mathbf{1 . 3 9}$ \\
\hline
\end{tabular}

From Table 7, the results illustrated teachers' skills about spreadsheets and database skills. The "usage of Excel tools and spreadsheet" was classified with the highest mean $(\mathrm{M}=2.95$; S.D. $=1.38)$, where "creating database and spreadsheet usage" $(\mathrm{M}=2.92$; S.D. $=1.37)$ was next, followed by "entering numerical data into the cells" $(\mathrm{M}=2.90$; S.D. $=1.40)$. However, the "use of spreadsheet" which was ranked last is represented by the mean was $(\mathrm{M}=2.82$; S.D = 1.41). These findings predicted that some of the teachers who are popular of using Excel software for students' evaluation and insert the data into the results of the examination period whether in mid or the final exam.

Table 8. Handling Files Skills $(\mathrm{N}=168)$

\begin{tabular}{lll}
\hline Skills & M & S.D. \\
\hline It is easy to me organize computer files in folder and subfolder & 2.73 & 1.45 \\
Storing files using a USB device or a memory stick & 2.71 & 1.49 \\
Storing information on a CD or DV & 2.32 & 1.44 \\
Creating and managing files and folders & 2.76 & 1.50 \\
Copying and moving files into different folders for storage & 2.69 & 1.46 \\
Total & $\mathbf{2 . 6 4}$ & $\mathbf{1 . 5 1}$ \\
\hline
\end{tabular}

As shown in table 8 , the highest mean of handling files was "creating and managing files and folders skills" $(\mathrm{M}=$ 2.76; S.D. = 1.50), followed by "organizing computer's files in folder and subfolder" $(\mathrm{M}=2.73$; S.D. = 1.45). "Skills of storing files using a USB device or a memory stick" (M = 2.71; S.D. = 1.49) was next, followed by "copying and moving files into different folders for storage skills" $(\mathrm{M}=2.69$; S.D. $=1.46)$. And finally "storing information on a CD or DVD skills" $(\mathrm{M}=2.32$; S.D. $=1.44)$.

Table 9. The Internet Usage Skills $(\mathrm{N}=168)$

\begin{tabular}{llc}
\hline Skills & M & S.D. \\
\hline Logging onto the internet & 2.23 & 1.40 \\
Searching for information using search engines such as Google & 2.15 & 1.41 \\
Download and upload materials from/ to website & 2.45 & 1.45 \\
Creating, sending and receiving e-mails & 2.52 & 1.47 \\
Adding attachments to an e-mail & 2.59 & 1.48 \\
I have social networks account (Facebook, WhatsApp, Twitter, Youtube...) & 2.61 & 1.58 \\
Total & 2.43 & 1.51 \\
\hline
\end{tabular}

Table 9, indicated to the internet usage skills and the statistical analysis which revealed that the "social networks account (Facebook, WhatsApp, Twitter, Youtube ...)" were the highest skill sets associated with internet usage $(\mathrm{M}=2.61$; S.D. $=1.58)$ among the respondent, followed by sending attachments through e-mail skills" $(\mathrm{M}=2.59$; S.D. $=1.48)$. "Creating, sending and receiving e-mails" $(\mathrm{M}=2.52$; S.D. $=1.47)$ was placed, and then "download and 
upload materials from/ to website" $(\mathrm{M}=2.45$; S.D. $=1.45)$, followed by "logging onto the internet" $(\mathrm{M}=2.23$; S.D. $=1.40)$. Finally, "searching for information using search engines such as Google skills" $(M=2.15$; S.D. $=1.41)$ were rated the last. Since teachers have the skill to use the Internet through social networking sites, this indicates that most of them use smartphones, which requires the design of training programs based on Mobile learning as a platform, that would suitable and convenient for their use of these devices for easy knowledge and experiences can be accessed to them and thus not expensive.

\section{Discussion}

This aspect of the study presents the discussion; the meaning of the findings. It basically addresses the two research questions that were sought to be answered by the study.

\subsection{Research Question 1: Differences between TVET Teachers' ICT Skills Due to Their Demographic Factors}

Demographically, the study found that there was no any difference due to the gender; all the TVET teachers are the same level of skills. Whereas, the results show that majority of TVET teachers were more than 40 years of age, where very few respondents represented the digital generation. Hence, the study reported that the younger teachers were higher skills particularly in Word processing then Spreadsheet and databases, this results agreed with (Alazam et al., 2012; Bennett et al., 2008; Elstad \& Christophersen, 2017). Therefore, younger teachers were more associative with ICT usage in the TVET institutions as reported in the findings. Regardless of the diversity of ICT skill sets among teachers of Sudan and in comparison with other countries, the findings of this study indicated that, the current appointment of teachers in Sudan to TVET institutions have moderate skills about ICT which can be taken into account with little focused of training programs the result may attribute to the courses which had been taught in technical education college. This approach may prepare foundations for the integration of ICT into the teacher training for TVET programs in the future as teaching and resources become available.

The largest group of teacher's work experience was found to be between ( $0-4$ years of experience). This implies that teachers who are aged 30-34 years old have higher levels of ICT skills since they have received ICT courses and educational technology program when they were at the college. This can be supported by the findings of the study which indicate that the younger teachers had the higher ICT skills as compared to their aged counterparts as well as years of experience (Alazam et al., 2012). These findings further support the findings of the Survey of the Department of Education and Science (McNamara \& O'Hara, 2008) has found that teachers below the age of 30 years had high ICT skills proficiency in the teaching process. However, this indicates that management system of TVET should continue to develop and maintain the skills' improvement among the teachers through in-service training, workshops, seminars and joint programs.

Although the findings also indicated that among the TVET teachers' qualification, (Others) had maximum respondents with qualifications including; certificates and diplomas, the highest qualification recorded from the study was bachelor's degree. However, the results showed that Word processing skills and Spreadsheet and databases are the most skills teachers have between (Bachelor degree and others) therefore, this result interpreted that most of the TVET teachers use ICTs frequently as school administration and student affairs. This implies that the higher qualification of teachers, the higher the ICT skills deemed to be acquired among teachers. This means that if TVET management and authorities need teachers with high ICT skills, the appointment of teachers should be influenced their ICT potentials.

\subsection{Research Question 2: The Basic ICT Skills of TVET Teachers}

The basic ICT skills particularly computer use as the main target of this study among TVET teachers, the results discovered that the most teachers were possessed the knowledge of using basic Word processing functions. This indicates that, when it comes to the word processing skills among the TVET teachers of Sudan, they can only use basic word functions professionally and some were not. This can be attributed to the inadequate ICT resources and opportunities to practice or using a computer in their daily work (Elemam, 2016). The findings, therefore, support a couple of findings from some studies (Gray \& Souter, 2003; Tella et al., 2007). Another contributing factor is the fact that, the teaching and learning instructions in the TVET schools were found to be traditionally inclined especially in terms of information sheet preparation among students, assessment, and even lesson plans. The previous findings correspond with the relative areas where computers and ICT could be used which were found absent among the TVET teachers in Sudan.

On the other hand, with respect to skills involving the use of spreadsheets and databases, the study demonstrated that using Excel tools was the key skill among TVET teachers which corresponds with (Elemam, 2016) study conducted 
in academy secondary schools intended to examine the barriers that hinders the implementation of ICT at five secondary schools in Khartoum State. Although (Elemam, 2016)study found that basic skills in spreadsheet usage were not quite enough for the use of Excel, the researcher, however, added that this study indicated that teachers were not familiar with the execution of Excel software in their daily works. These results predicted that may be attributed to a few teachers who use this program in his work and the rest of teachers only use the notebooks.

In terms of handling files, the study found that majority of teachers could manage files; meaning most teachers could interact with the computer more satisfactorily. Finally, examining internet usage among TVET teachers, the study found that majority of the respondents most frequently used social media in spite of the unavailability of the internet connectivity in schools. They resort to their data bundles on smartphones in particular. This finding corresponds with (Elemam, 2016) found that most of the teachers were more acquainted to use the internet and social media. However, these findings collectively contradict (Tella et al., 2007) who found less usability of internet/social media and email. TELLA attributed the challenges of ICT usage among teachers to unavailability of ICT resources whereas the (McNamara \& O'Hara, 2008) reported an advanced level of internet and social media navigation skills. The teachers had been found they have had frequent use of the internet and social media mostly through the use of their cellphones and a few of them used their personal computers. Generally, in Sudan, the internet can be easy to access from the teachers' side, but it is not for free it depends on the internet package, period and price.

\section{Conclusion}

From the study results, it was found that based on the teachers' demographic information, the younger teachers were more digitally advanced when compared with their colleagues. In addition, the basic skill of computer utilization was a basic word function in the aspect of the word processing skills which found the majority of teachers use it. Whereas the spreadsheets and database skills represented as the main ICT skills teachers possessed, as well as managing files. And only the social media had been used among the respondents rather than internet usage for searching information, regarding the subjects and materials which might be used for lesson planning or courses design and syllabus for their students.

Based on our findings, we strongly recommended that, as a priority work should be taken into account is that; long-term of strategic plan for ICT integration in TVET system, preparing technical schools and artisan institutions as well as vocational training centers with enough computer devices and internet connectivity such as WLAN service, ICT training should be integrated into certificate and diploma programs to enable pre-service teachers to acquire the necessary skills needed for the TVET ICT programs. In-service teacher training, workshops and seminars should be organized to train/educate teachers in the system to bridge the ICT skills variation among teachers and to give the teachers an opportunity to collaborate and exchange their experiences and efforts, above all mentioned there should be a very clear curriculum for teacher training program characterized by the international standards.

This research has encountered with some limitation, which represented as; there was some misunderstanding between general management of TVET system and the general secondary education management. Consequently, the researcher does not access some teachers to evaluate them besides that some teachers refused to fill the questionnaires as well as the time limit because of the difference of the researcher study place in (China) and the field of study in Sudan.

Finally, information literacy, media literacy as well as information and communication technologies are being strongly recommended to be included in the teacher-training program. Thus, the TVET teachers can be able to use the ICT technology anywhere and anytime for their students' benefit in the presence of all the aids of practice. Above all mentioned the study suggested that there should be a central electronic library to allow teachers to visit and prepare their materials and strengthening the weaknesses they have. For farther research in this study, we recommend to study the teacher professional development (TPD) based on ICT skills, evaluate teachers' technological pedagogical and content knowledge (TPACK).

\section{Acknowledgements}

We are grateful to the NENU (Northeast Normal University) for the support this study and all the TVET teachers who were helped in data collection procedure.

\section{References}

Abdulrasool, S. M., \& Mishra, R. (2009). Using Computer Technology Tools to Improve the Teaching-Learning 
Process in Technical and Vocational Education: Mechanical Engineering Subject Area. International Journal of Learning, 15(12), 155-168. https://doi.org/10.18848/1447-9494/CGP/v15i12/46059

Ahmed, A. (2015). Managing Information and Communication Technology in Sudanese Secondary School. Journal of Education and Practice, 6(32), 1-8.

Ahmed, H. (2010). Building Capacity of Teachers and Trainers in Technical and Vocational Education and Training (TVET) in Sudan.

Alamin, H. A. A., \& Elgabar, E. E. A. (2014). Success Factors for Adopting E-learning Application in Sudan. International Journal of Soft Computing and Engineering (IJSCE), 3(4), 128-131.

Alazam, A.-O., Bakar, A. R., Hamzah, R., \& Asmiran, S. (2012). Teachers' ICT skills and ICT integration in the classroom: the case of vocational and technical teachers in Malaysia. Creative Education, 3, 70. https://doi.org/10.4236/ce.2012.38B016

Alseddiqi, M., Mishra, R., \& Abdulrasool, S. M. (2010). Improving teaching and learning effectiveness in engineering education. The International Journal of Learning, 17(9), 11-26. https://doi.org/10.18848/1447-9494/CGP/v17i09/47250

Ananiadou, K., \& Claro, M. (2009). 21st century skills and competences for new millennium learners in OECD countries. OECD Education Working Papers, No. 41, OECD Publishing, Paris. https://doi.org/10.1787/218525261154

Bennett, S., Maton, K., \& Kervin, L. (2008). The "digital natives" debate: A critical review of the evidence. British Journal of Educational Technology, 39(5), 775-786. https://doi.org/10.1111/j.1467-8535.2007.00793.x

Bezjak, J. (2010). Contemporary engineer pedagogic's project research-using multimedia at technology classes in technical and vocational schools. Procedia-Social and Behavioral Sciences, 2(2), 407-411. https://doi.org/10.1016/j.sbspro.2010.03.035

Boyd, D., Lankford, H., Loeb, S., Rockoff, J., \& Wyckoff, J. (2008). The narrowing gap in New York City teacher qualifications and its implications for student achievement in high-poverty schools. Journal of Policy Analysis and Management, 27(4), 793-818. https://doi.org/10.1002/pam.20377

Chai, C. S., Koh, J. H. L., \& Tsai, C.-C. (2010). Facilitating preservice teachers' development of technological, pedagogical, and content knowledge (TPACK). Educational Technology \& Society, 13(4), 63-73.

Chai, C. S., Tan, L., Deng, F., \& Koh, J. H. L. (2017). Examining pre-service teachers' design capacities for web-based 21st century new culture of learning. Australasian Journal of Educational Technology, 33(1), 1-20.

Demetriadis, S., Barbas, A., Molohides, A., Palaigeorgiou, G., Psillos, D., Vlahavas, I., ... Pombortsis, A. (2003). "Cultures in negotiation": teachers' acceptance/resistance attitudes considering the infusion of technology into schools. Computers \& Education, 41(1), 19-37. https://doi.org/10.1016/S0360-1315(03)00012-5

Elemam, A. E. (2016). Barriers to Implementation of Information and Communication (ICT) in Public Sudanese Secondary Schools: Teacher's Prospective. Journal of Sociological Research, 7(1), 33-43. https://doi.org/10.5296/jsr.v7i1.8956

Elstad, E., \& Christophersen, K.-A. (2017). Perceptions of digital competency among student teachers: Contributing to the development of student teachers' instructional self-efficacy in technology-rich classrooms. Education Sciences, 7(1), 27. https://doi.org/10.3390/educsci7010027

Göksün, D. O., \& Kurt, A. A. (2017). The relationship between pre-service teachers' use of 21 st Century learner skills and 21st Century teacher skills. Egitim ve Bilim, 42(190), 107-130. https://doi.org/10.15390/EB.2017.7089

Gray, D. S., \& Souter, N. (2003). Secondary science teachers' use of, and attitude towards ICT in Scotland. A Report, University of Strathclyde, Glasgow, UK.

Guzman, A., \& Nussbaum, M. (2009). Teaching competencies for technology integration in the classroom. Journal of Computer Assisted Learning, 25(5), 453-469. https://doi.org/10.1111/j.1365-2729.2009.00322.x

Hamdy, H. (2007). ICT in Education in Sudan, Survey of ICT and Education in Africa: Sudan Country Report. Sudan. Retrieved from https://www. infodev. org/infodevfiles/resource/InfodevDocuments_430. pdf.

Hatlevik, O. E., Scherer, R., \& Christophersen, K.-A. (2017). Moving beyond the study of gender differences: An analysis of measurement invariance and differential item functioning of an ICT literacy scale. Computers \& 
Education, 113, 280-293. https://doi.org/10.1016/j.compedu.2017.06.003

Hyland, K. (1990). Literacy for a new medium: Word processing skills in EST. System, 18(3), 335-342. https://doi.org/10.1016/0346-251X(90)90006-Q

Jamšek, J., \& Kocijancic, S. (2007). Computer based laboratory course "From Electricity to Electronics." Radovljica, SLOVENIA.

Latchem, C. (2017). ICTs, Blended Learning and TVET Transformation. Using ICTs and Blended Learning in Transforming TVET, 27.

Law, N. (2000). Changing classrooms \& changing schools: a study of good practices in using ICT in Hong Kong Schools. CITE, Faculty of Education, University of Hong Kong.

McNamara, G., \& O'Hara, J. (2008). Trusting schools and teachers: Developing educational professionalism through self-evaluation (Vol. 8). Peter Lang.

Melvin, L. (2011). How to keep good teachers and principals: practical solutions to today's classroom problems. R\&L Education.

Mingaine, L. (2013). Challenges in the implementation of ICT in Public secondary schools in Kenya. Int. J. Soc. Sci. Educ, 4, 224-238. https://doi.org/10.5539/jel.v2n1p32

Peeraer, J., \& Van Petegem, P. (2011). ICT in teacher education in an emerging developing country: Vietnam's baseline situation at the start of "The Year of ICT." Computers \& Education, 56(4), 974-982. https://doi.org/10.1016/j.compedu.2010.11.015

Shamim, M. R. H., \& Raihan, M. A. (2016). Effectiveness of Using ICTs to promote teaching and learning in technical education: Case of Bangladesh. International Journal of Vocational and Technical Education, 8(2), $12-19$.

Tairab, A., \& Ronghuai, H. (2017). Analyzing ICT Policy in K-12 Education in Sudan (1990-2016). World Journal of Education, 7(1), 71. https://doi.org/10.5430/wje.v7n1p71

Tairab, A., Huang, R., Chang, T.-W., \& Zheng, L. (2016). A Framework to Promote ICT in K-12 Education in Developing Countries: A Case Study in Sudan. In International Conference on Blending Learning (pp. 312-323). Springer. https://doi.org/10.1007/978-3-319-41165-1_28

Tella, A., Tella, A., Toyobo, O. M., Adika, L. O., \& Adewuyi, A. A. (2007). An assessment of secondary school teachers uses of ICT's: Implications for further development of ICT's use in Nigerian secondary schools. TOJET: The Turkish Online Journal of Educational Technology, 6(3).

Trilling, B., \& Fadel, C. (2009). 21st Century Skills, Learning for Life in Our Times. San Francisco, CA: John Willey $\&$ Sons. Inc.

Tsai, C.-C., \& Chai, C. S. (2012). The“ third"-order barrier for technology-integration instruction: Implications for teacher education. Australasian Journal of Educational Technology, 28(6), 1057-1060. https://doi.org/10.14742/ajet.810

Union, A. (2007). Strategy to revitalize technical and vocational education and training (TVET) in Africa. In Meeting of the Bureau of the Conference of Ministers of Education of the African Union (COMEDAF II+) (pp. 29-31). 